\title{
Enhanced specific antibody productivity of calcium alginate-entrapped hybridoma is cell line-specific
}

\author{
Gyun Min Lee ${ }^{1}$, Sang Jick Kim ${ }^{1}$ and Bernhard O. Palsson ${ }^{2}$ \\ ${ }^{1}$ Department of Biotechnology, Korea Advanced Institute of Science and Technology 373-1, Kuseong-Dong, \\ Yuseong-Gu, Taejun 305-701, Korea; ${ }^{2}$ Department of Chemical Engineering, University of Michigan, Herbert $H$. \\ Dow Building, Ann Arbor, MI 48109, USA
}

Received 7 December 1993; accepted 18 April 1994

Key words: Flow cytometry, hybridoma, immobilization, specific antibody productivity

\begin{abstract}
In order to determine whether the enhanced specific antibody productivity $\left(q_{M A b}\right)$ of calcium alginate-entrapped hybridoma is cell line-specific, calcium alginate-entrapped hybridomas (4A2 and DB9G8) were cultivated under the condition where we had previously observed significantly enhanced $q_{M A b}$ of calcium alginate-entrapped $\mathrm{S} 3 \mathrm{H} 5 / \gamma 2 \mathrm{bA} 2$ hybridoma. Unlike S3H5/ $\gamma 2 \mathrm{bA} 2$ hybridoma, neither 4A2 nor DB9G8 hybridomas showed persistently enhanced $q_{M A b}$ when they were entrapped in calcium alginate beads. The enhanced $q_{M A b}$ of entrapped 4A2 and DB9G8 hybridomas, which was 2-3 times higher than the $q_{M A b}$ of free-suspended cells in a control experiment, was observed only during the early stage of the culture. During the early stage of the culture, the viable cell concentration decreased probably due to cell damage during the entrapment process. As cell growth resumed, the $q_{M A b}$ decreased to the similar level of $q_{M A b}$ of free-suspended cells within 5-7 days. Thus, we conclude that the enhanced $q_{M A b}$ of calcium alginate-entrapped hybridomas is cell line-specific.
\end{abstract}

\section{Introduction}

A high volumetric monoclonal antibody (MAb) productivity, which can be achieved by increasing the cell concentration and/or increasing the specific MAb productivity $\left(q_{M A b}\right)$, is desired for economic production of MAbs. We previously reported that entrapment of $\mathrm{S} 3 \mathrm{H} 5 / \gamma 2 \mathrm{bA} 2$ hybridoma into calcium alginate beads significantly enhanced the $q_{M A b}$ as well as the cell concentration (Lee et al., 1991a, 1993). The enhanced $q_{M A b}$ of entrapped hybridoma cells was not unique to $\mathrm{S} 3 \mathrm{H} 5 / \gamma 2 \mathrm{bA} 2$ hybridoma in spinner flasks. A significant enhancement of $q_{M A b}$ has been also observed for SPO1 hybridoma in alginate/agarose composite gel in a packed-bed perfusion reactor (Shen $e$ t al., 1992), and for hybridoma cells in collagen microspheres in fluidized perfusion bioreactor (Ray et al., 1990). Accordingly, the use of entrapped hybridomas could potentially improve the economics of in vitro production of MAbs.
Contrary to these observations of enhanced $q_{M A b}$, other researchers have reported that the $q_{M A b}$ of entrapped hybridomas was comparable with that of hybridomas grown in suspension (de la Broise et al., 1992; Shirai et al., 1987; Sinacore et al., 1989; Wohlpart et al., 1991). These results were obtained using several hybridoma cell lines immobilized in calcium alginate beads. The differences between the results we reported (Lee et al., 1991a, 1993) and those found by others (de la Broise et al., 1992; Shirai et al., 1987; Sinacore et al., 1989; Wohlpart et al., 1991) are possibly due to the different culture conditions under which the alginate beads were carried, or due to the differences in the cell line used. Considering the importance of $q_{M A b}$, it is necessary to determine whether the enhanced $q_{M A b}$ of entrapped hybridoma is cell line-specific or whether the differences in the results reported are due to the cell culture conditions. In our previous report, we showed that cell culture conditions can influence the $q_{M A b}$ of calcium alginate-entrapped $\mathrm{S} 3 \mathrm{H} 5 / \gamma 2 \mathrm{bA} 2$ hybridoma 
significantly (Lee et al., 1993). Thus, the remaining question to be addressed is to determine whether the enhanced $q_{M A b}$ of entrapped hybridomas is cell linespecific.

In the present study, we cultivate calcium alginateentrapped murine hybridomas under the condition where we observed the significantly enhanced $q_{M A b}$ of calcium alginate-entrapped $\mathrm{S} 3 \mathrm{H} 5 / \gamma 2 \mathrm{bA} 2$ hybridoma, and thereby, determine whether the enhanced $q_{M A b}$ of entrapped hybridomas is indeed cell line-specific.

\section{Materials and methods}

\section{Cell line, culture maintenance, and culture medium}

Two murine hybridomas were used in this study. One was Xoma's hybridoma cell line 4A2 adapted to serumfree medium (DMEM:F12 (1:1) supplemented with 20 $\mathrm{nM}$ sodium selenite, $20 \mu \mathrm{M}$ ethanolamine, $5 \mathrm{mg} / \mathrm{L}$ bovine insulin, and $30 \mathrm{mg} / \mathrm{L}$ bovine transferrin). The cells were provided in a frozen state by Xoma Corporation (Berkeley, CA, USA). The antibody produced by this cell line is $\operatorname{IgG}_{2 a}$ and the fusion partner used was NS1. The other was DB9G8 hybridoma (ATCC HB124) provided at frozen state by American Type Culture Collection (Rockville, MD, USA). This cell line produces an $\mathrm{IgG}_{2 a}$ against bovine insulin and the fusion partner used was Sp2/0-Ag14 (Schroer et al., 1983).

Inocula for both free-suspended and entrapped cell cultures were prepared by thawing cells. The cells were subcultured in $25 \mathrm{~cm}^{2}$ T-flasks (Bellco Glass, Inc., Vineland, NJ, USA) in a $5 \% \mathrm{CO}_{2}$ /air mixture, humidified at $37^{\circ} \mathrm{C}$. The cells were diluted $1: 5$ with a fresh medium every two or three days.

Culture medium used for 4A2 hybridoma was DMEM:F12 (1:1) supplemented with $20 \mathrm{nM}$ sodium selenite, $20 \mu \mathrm{M}$ ethanolamine, $5 \mathrm{mg} / \mathrm{L}$ bovine insulin, and $30 \mathrm{mg} / \mathrm{L}$ bovine transferrin. Glucose and glutamine concentration were $17.51 \mathrm{mM}$ and $6 \mathrm{mM}$, respectively. All supplements were obtained from Sigma (St. Louis, MO, USA). Culture medium used for DB9G8 hybridoma was Iscove's modified Dulbecco's medium (IMDM, Sigma) supplemented with $10 \%$ fetal bovine serum (FBS, HyClone, Logan, UT, USA). No antibiotics were used in any cultures.

\section{Immobilization}

Cells were entrapped in gel beads of calcium alginate (Keltone LV, Kelco, Chicago, IL, USA) as described previously (Lee and Palsson, 1990). For entrapped cell culture, $30 \mathrm{ml}$ of a $1.5 \%(\mathrm{w} / \mathrm{v})$ sodium alginate solution was mixed with different concentrations of cells. The alginate/cell suspension was pumped into $1 \mathrm{~L}$ of a cold $1.5 \% \mathrm{CaCl}_{2}$ solution. Different sizes of gel beads with diameters in the range of $0.9-1.2 \mathrm{~mm}$ were obtained by changing air flow rates in an air-syringe droplet generator (Lim, 1984, 1988). After several washings, these beads were transferred into spinner flasks.

\section{Cell culture}

Almost identical experiments except initial cell concentration and bead size were carried out for $4 \mathrm{~A} 2$ and DB9G8 hybridomas. Same inocula prepared from Tflask culture were used for both free-suspended and entrapped cell cultures.

For the free-suspended (non-entrapped) cell culture, which was performed as a control, exponentially growing cells were inoculated into spinner flasks (Bellco, Vineland, NJ, USA) containing $50 \mathrm{ml}$ of medium. The initial densities used for 4A2 and DB9G8 hybridomas were approximately $1.8 \times 10^{5}$ cells $/ \mathrm{ml}$ and $1.4 \times$ $10^{5}$ cells $/ \mathrm{ml}$, respectively. The cells were cultivated in a repeated-fed batch mode, and were always passed in the late exponential phase. The cells were diluted 1:5 with a fresh medium.

For the entrapped cell culture, the entrapped cells were inoculated into a spinner flask. The working volume of the spinner flask (Bellco) was $100 \mathrm{~mL}$. Like the free-suspended cell culture, the entrapped cells were cultivated in a repeated-fed batch mode. To exchange the medium, the beads were first allowed to settle, and then 60-65 ml of spent medium was replaced by fresh medium either once or twice a day. After ca. 16 days of cultivation, the alginate beads entrapping the cells were recovered aseptically from the spinner flask and were dissolved in a sterile isotonic citrate solution (3\% aqueous sodium citrate diluted $1: 1$ in $0.9 \%$ $\mathrm{NaCl}$ adjusted to $\mathrm{pH} 7.4$ ) for 10 minutes with gentle vortexing ( $\mathrm{Lim}, 1984$ ). The cells were centrifuged at $1500 \mathrm{rpm}$ for 10 minutes and then washed with fresh medium. The recovered, free-suspended cells were reinoculated into a spinner flask containing $50 \mathrm{ml}$ of medium. The cells were diluted $1: 5$ with medium every two or three days (refer to Figs. 3 and 6). 
With DB9G8 hybridoma, we carried out two more sets of entrapped cell cultures. For the first set of experiment, the cells were entrapped into two different sizes of calcium alginate beads. The diameters of calcium alginate beads used were 0.9 and $1.2 \mathrm{~mm}$, respectively. For the second set of experiment, two different initial concentrations were used. The initial concentrations used were $1.0 \times 10^{6}$ and $2 \times 10^{6}$ cells $/ \mathrm{ml}$, respectively.

\section{Analytical methods}

Cell growth was monitored by counting viable cells with a hemocytometer. Viable cells were distinguished from dead cells by the trypan blue dye exclusion method. The cell culture suspension was centrifuged and the supernatant was aliquoted and kept frozen at $-80{ }^{\circ} \mathrm{C}$. Glucose and lactate were measured using a glucose/lactate analyzer (Model 2000, Yellow Spring, OH, USA). Glutamine concentration was analyzed with an L-glutamic acid kit (Boehringer Mannheim, Indianapolis, IN, USA) in conjunction with $\mathrm{L}$-asparaginase (Boehringer Mannheim).

The total secreted antibody, $\operatorname{IgG}_{2 a}$, was quantified using an enzyme linked immunosorbent assay (ELISA) as described previously (Lee et al., 1989). Standard mouse $\operatorname{IgG}_{2 a}$ was provided by Xoma Corporation and Southern Biotechnology Associates, Inc. (Birmingham, AL, USA). Alkaline phosphatase (AP) labeled goat anti-mouse $\operatorname{IgG}_{2 a}$ (heavy chain specific, Southern Biotechnology Associates, Inc.) was used as an enzyme antibody conjugate.

To count the cells and prepare the flow cytometric samples from the entrapped cell culture, $60-100$ gel beads containing the cells were first dissolved in isotonic citrate solution for 5-10 minutes. The total cell concentration and viability were then determined by the trypan blue dye exclusion method and manual cell counting on a hemocytometer. Cell viability of hybridoma does not decrease significantly during a 10 minute citrate treatment (Lee et al., 1991b). The amounts of intracellular antibody $\left(\operatorname{IgG}_{2 a}\right)$ and DNA were measured simultaneously using flow cytometry as described previously (Lee and Palsson, 1989). Fluorescein-isothiocyanate (FITC)-labeled goat antimouse $\operatorname{IgG}_{2 a}$ (heavy chain specific, Southern Biotechnology) was used as an antibody conjugate. Cell samples for comparison were stained and analyzed at the same time and condition to avoid day-to-day variations in flow cytometer measurements.
Evaluation of specific growth rates, consumption, and production rates

The specific growth rate $(\mu)$, glucose uptake rate $\left(q_{g l u}\right)$, lactate production rate $\left(q_{l a c}\right)$, and specific MAb productivity $\left(q_{M A b}\right)$, were based on the data obtained from each batch cycle and were evaluated as described earlier (Lee et al., 1991a). The volumetric MAb productivity, $r_{M A b}$, is defined as follows:

$$
r_{M A b}=\frac{[M A b]_{t c}-[M A b]_{o}}{t c}
$$

where tc denotes the total cell culture time of each batch cycle, and $[\mathrm{MAb}]_{t c}$ and $[\mathrm{MAb}]_{o}$ denote the final and initial MAb concentrations of each batch cycle, respectively.

\section{Results}

In order to determine whether the enhanced $q_{M A b}$ of entrapped hybridomas is cell line-specific, we performed both free-suspended and entrapped cell cultures in spinner flasks. We also carried out freesuspended cell cultures with the cells recovered from the calcium alginate beads to study the transient behaviour of the cells from the immobilized state to free-suspended state.

\section{A2 Hybridoma}

\section{Free-suspended (non-entrapped) cell culture}

To compare free-suspended cells with entrapped cells with regard to their growth, glucose consumption, lactate production, and MAb production characteristics, a free-suspended cell culture in a spinner flask was carried out. An initial viable cell concentration was $1.8 \times 10^{5}$ cells $/ \mathrm{ml}$. To maintain the cells in exponential growth phase, the cells were transferred when the viable cell concentration reached approximately 1.0 $\times 10^{6}$ cells $/ \mathrm{ml}$ (Fig. 1A). When the overgrown cells were transferred, the cells either experienced a long lag phase or died. Average specific growth rate of the cells was $0.89 \pm 0.16 /$ day ( \pm standard deviation). The glucose and lactate concentrations during the culture were measured (Fig. 1B). The glucose concentration decreased markedly during each batch cycle, and glucose utilization was accompanied by a corresponding accumulation of lactate. Neither glucose nor glutamine 


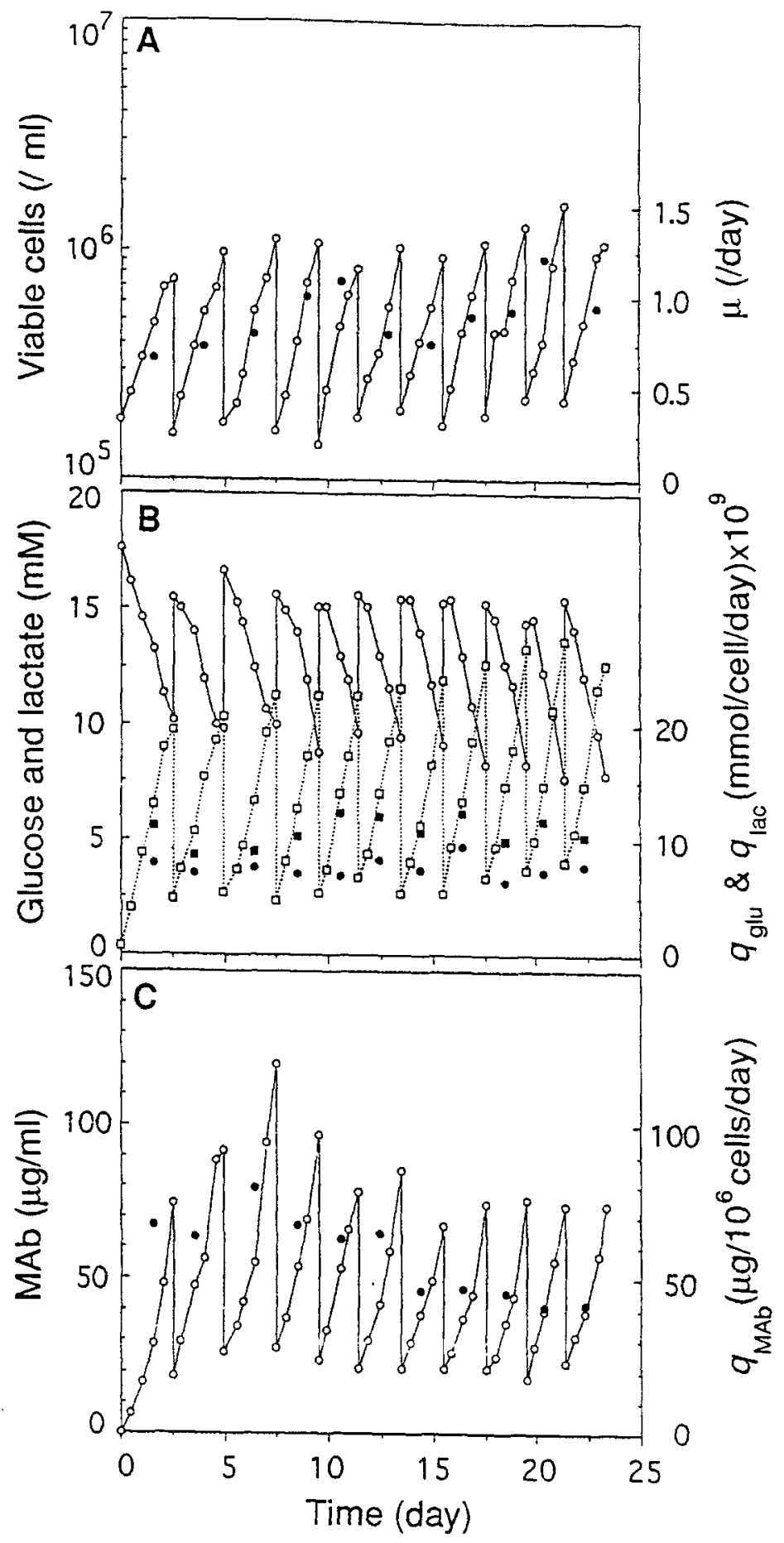

Fig. 1. Free-suspended 4A2 hybridoma culture. (A) viable cell concentration (o) and specific growth rate, $\mu,(\bullet)$. (B) Glucose concentration $(\mathrm{o})$, lactate concentration (ㅁ), $q_{g l u}(\bullet)$, and $q_{l a c}(\boldsymbol{\bullet})$. (C) MAb concentration (o) and $q_{M A b}(\bullet)$. 
(data not shown) was limited during the culture. The average glucose consumption rate $\left(q_{g l u}\right)$ and lactate production rate $\left(q_{g l u}\right)$ were $7.51 \pm 0.83$ and 10.71 $\pm 1.31 \mathrm{mmol} / 10^{9}$ cells/day, respectively. The average ratio of lactate produced to glucose consumed, $Y$ lac $/ g l u$, was $1.43 \pm 0.17 \mathrm{mmol} / \mathrm{mmol}$.

MAb concentrations and $q_{M A b}$ are shown in Fig. 1C. The $q_{M A b}$ of the cells was not constant during the culture, as indicated by the decreased $q_{M A b}$ after subculturing six times. The average $q_{M A b}$ of the first six subcultures was $67.58 \pm 6.24 \mu \mathrm{g} / 10^{6}$ cells/day, while that of the last five passages was $44.36 \pm 2.56$ $\mu \mathrm{g} / 10^{6}$ cells/day. As suggested by Hiller et al. (1991), the early loss of antibody productivity may be related to the recent thawing from liquid nitrogen. Hiller $e t$ al. (1991) observed that the antibody productivity of 4A2 hybridoma cells decreased soon after revival from liquid nitrogen storage and was stabilized after subculturing approximately 12 times. Miller (1987) also observed a dramatic decrease in antibody productivity of AB2-143.2 hybridoma during the first month after thawing, followed by gradual decline after that time. Inoculum used in this study was prepared by subculturing six times after thawing. Thus, the decreased $q_{M A b}$ of the cells observed in this study is consistent with the observation made by Hiller et al. (1991).

\section{Entrapped cell culture}

Unlike the free-suspended cell culture, the entrapped cell culture has a limit in the sampling frequency of alginate beads for cell counts. Because some beads need to be dissolved to count the cells, we lose approximately $1 \%$ of initial number of alginate beads for each sampling, thus lowering the cell concentration. The glucose and lactate concentrations were measured twice a day. These metabolite concentrations may indirectly indicate the changes in the cell concentration.

Figure 2 shows photomicrographs of entrapped cells. The diameter of calcium alginate beads was approximately $1.2 \mathrm{~mm}$. Initially, the cells were uniformly dispersed throughout the gel beads. Subsequent cell growth produced big clusters of the cells throughout the gel beads. Unlike $\mathrm{S} 3 \mathrm{H} 5 / \gamma 2 \mathrm{bA} 2$ hybridoma entrapped in calcium alginate beads, 4A2 hybridoma did not form linear spindle-shaped clusters of the cells.

Figure 3A shows the growth characteristics of the entrapped cells. An initial viable cell concentration and cell viability were $1.3 \times 10^{6}$ cells $/ \mathrm{ml}$ of medium and $83 \%$, respectively. The viable cell concentration as well as cell viability significantly dropped for the first
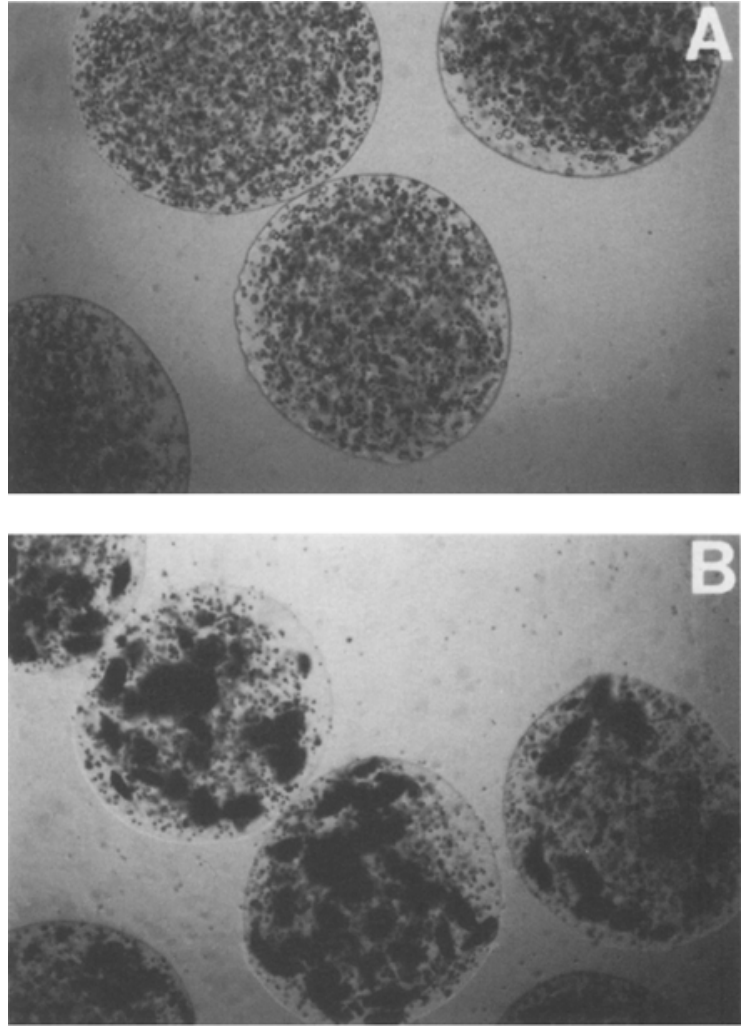

Fig. 2. Photomicrographs of calcium alginate-entrapped $4 A 2$ hybridoma cells: (A) day 3; (B) day 13.

4 days of cultivation. This decrease in viable cell concentration and viability may have occurred because of cell damage during the entrapment process (Lee et al, 1992). The viable cell concentration increased from $0.4 \times 10^{6}$ cells $/ \mathrm{ml}$ to $2.0 \times 10^{6}$ cells $/ \mathrm{ml}$ for the next 4 days of cultivation. After day $10,60-65 \mathrm{ml}$ of spent medium was replaced by fresh medium twice a day. The cell viability also improved from $21 \%$ to $43 \%$ during this period. After achieving the maximum viable cell concentration of $2.9 \times 10^{6}$ cells on day 10 , the viable cell concentration gradually decreased to $2.3 \times$ $10^{6}$ cells $/ \mathrm{ml}$ by the end of entrapped cell culture. The free-suspended cell concentration in the culture medium during the entrapped cell culture was less than 1.0 $\times 10^{5}$ cells $/ \mathrm{ml}$ which was neglected in the estimation of viable cell concentration in the entrapped cell culture. The cell viability of the free-suspended cells recovered from the calcium alginate beads improved by subsequent sub-cultures. After three passages, the 


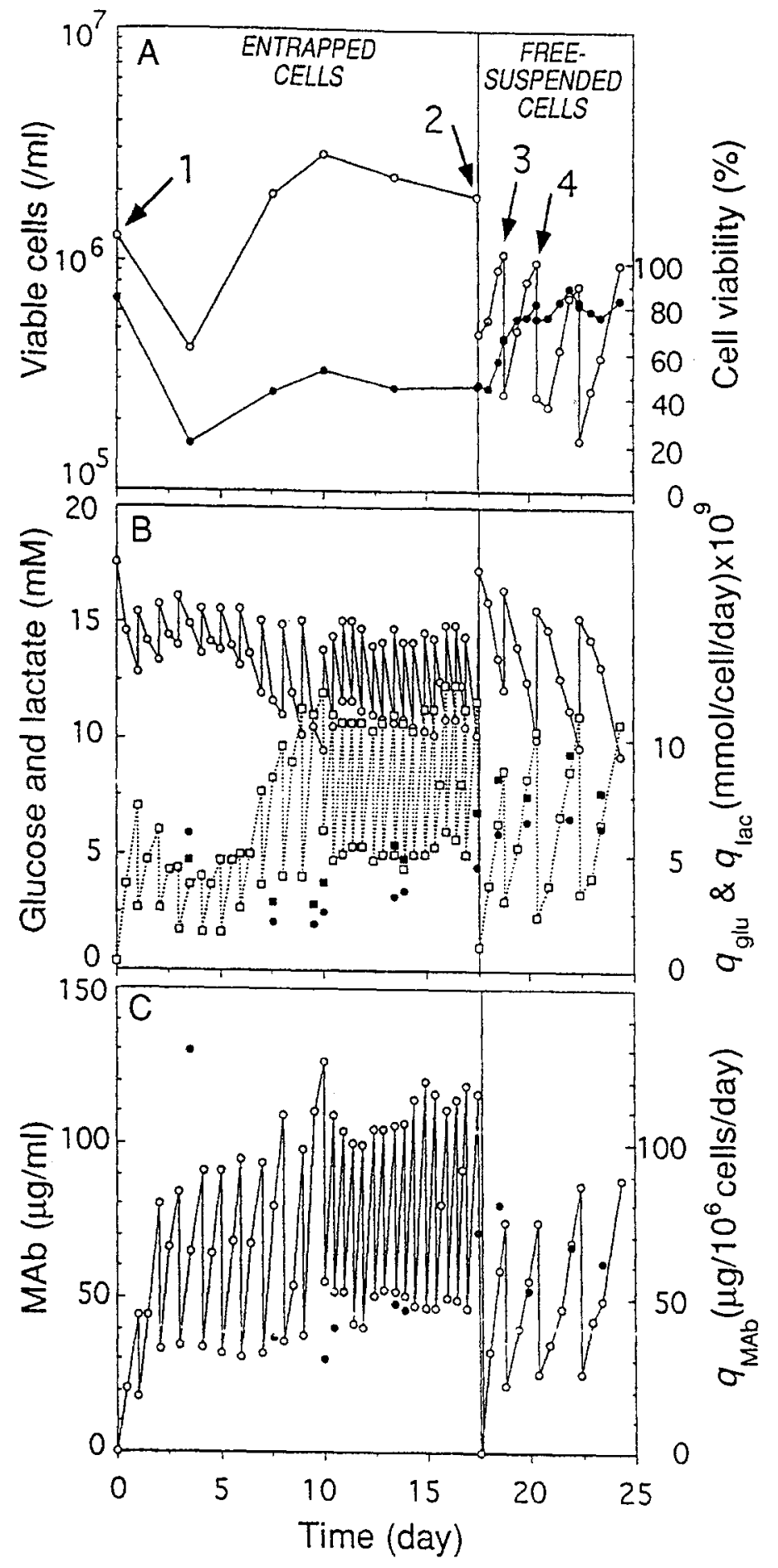

Fig. 3. Entrapped 4A2 hybridoma culture followed by free-suspended $4 \mathrm{~A} 2$ hybridoma culture. (A) viable cell concentration (o) and cell

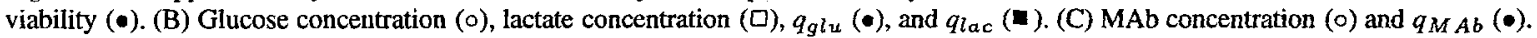


cell viability went up to approximately $82 \%$, which is close to the initial cell viability.

Figure $3 \mathrm{~B}$ shows the glucose and lactate concentrations during the culture. Glucose consumption and lactate production showed a similar pattern of changes in viable cell concentrations during the culture. Glucose consumption and lactate production decreased for the first 4 day of cultivation, and gradually increased until the viable cell concentration reached a maximum. Although the values of $q_{g l u}$ and $q_{l a c}$ were significantly varied during the entrapped cell culture, they were lower than the values obtained in the free-suspended cell culture (refer to Fig. 1B). The $q_{g l u}$ and $q_{l a c}$ of entrapped cells during the exponential growth phase were 2.03 and $2.92 \mathrm{mmol} / 10^{9}$ cells/day, respectively. These values were less than one third of the value obtained in the free-suspended cell culture. However, the $Y_{l a c / g l u}$ of entrapped cells except the data on day 4 was fairly constant at $1.46 \pm 0.19 \mathrm{mmol} / \mathrm{mmol}$ which is almost the same as the $Y_{l a c / g l u}$ of free-suspended cells in a control experiment. The $Y_{l a c / g l u}$ of entrapped cells on day 4 was $0.81 \mathrm{mmol} / \mathrm{mmol}$. On day 4 , the cells were preparing to grow after experiencing a notable loss of viability for first four day of cultivation. Accordingly, a significant portion of glucose consumed appeared to be used for biosynthesis and cell maintenance. When the free-suspended recovered from the beads were subcultured, the $q_{g l u}$ and $q_{l a c}$ of the cells rapidly increased to the same level of the free-suspended cells in a control experiment. Glutamine was not limited during the culture. When the medium was replaced twice a day, the glutamine concentration was maintained over $2.5 \mathrm{mM}$.

Figure $3 \mathrm{C}$ shows the MAb concentrations and $q_{M A b}$ during the culture. The $q_{M A b}$ of the entrapped 4A2 hybridoma was not increased during the culture except day 4 , as previously observed in an entrapped $\mathrm{S} 3 \mathrm{H} 5 / \gamma 2 \mathrm{bA} 2$ hybridoma. Thus, it appears that the enhanced $q_{M A b}$ of entrapped cells is cell line specific. When the medium was replaced twice a day, the average $q_{M A b}$ of the entrapped $4 \mathrm{~A} 2$ hybridoma was $51.34 \pm 13.65 \mu \mathrm{g} / 10^{6} \mathrm{cells} / \mathrm{day}$, which is close to the average value $\left(\cong 57.00 \pm 13.00 \mu \mathrm{g} / 10^{6}\right.$ cells/day) of free-suspended cells in a control experiment. When the free-suspended cells recovered from the alginate beads were subcultured, the $q_{M A b}$ increased to $65.31 \pm 11.53$ $\mu \mathrm{g} / 10^{6}$ cells/day, which is close to the average $q_{M A b}$ of free-suspended cells during the first six subcultures in a control experiment. The enhanced $q_{M A b}$ of entrapped cells was observed only around day 4 when the cell viability was lowest during the culture. The stressful condition, indicated by poor cell viability, may be
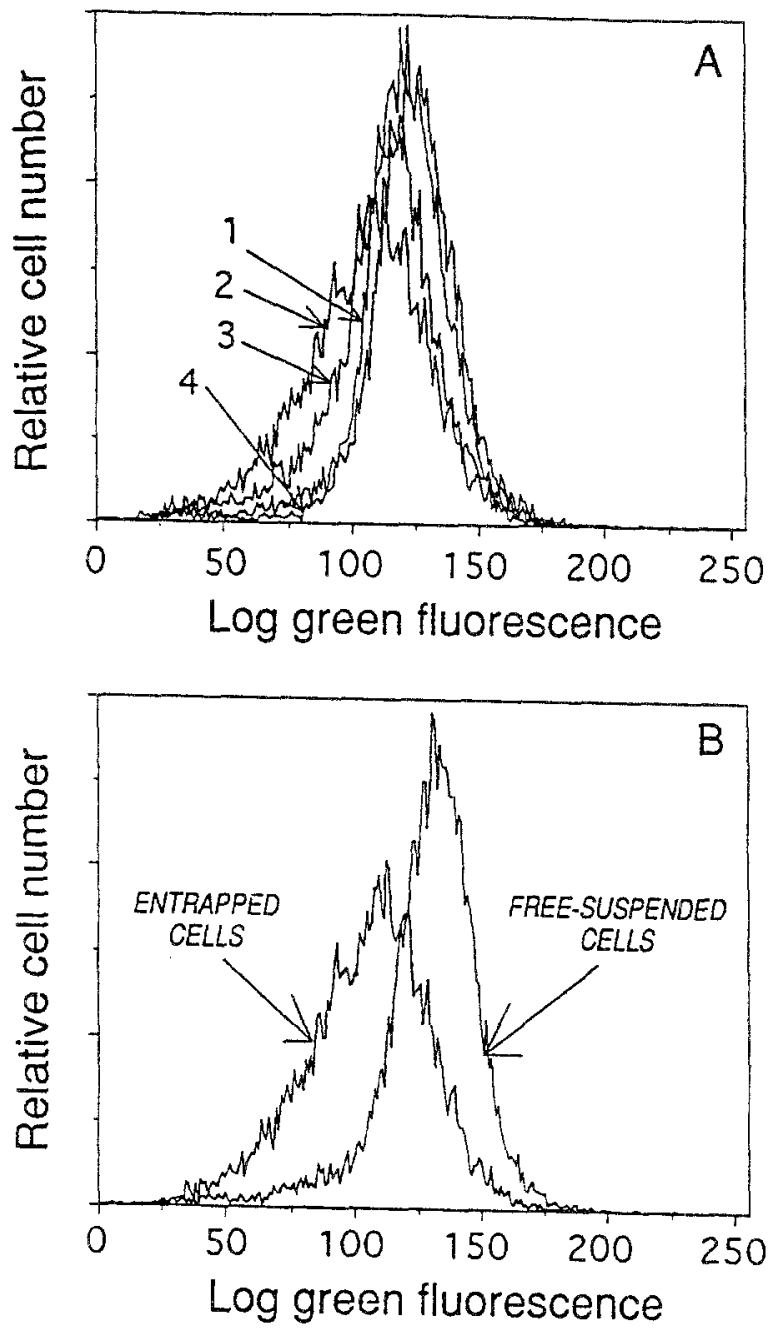

Fig. 4. Flow cytometric data of $4 A 2$ hybridoma: (A) Intracellular $\mathrm{MAb}$ histograms of the cells during the culture. Numbers in the histograms correspond to the arrows in Fig. 3A. (B) Intracellular $\mathrm{MAb}$ histograms of the free-suspended cells and the entrapped cells coexisting at the end of entrapped cell culture.

responsible for the enhanced $q_{M A b}$ of entrapped cells on day 4 . The $q_{M A b}$ of entrapped cells on day 4 was $130.90 \mu \mathrm{g} / 10^{6}$ cells/day.

Figure 4 shows the intracellular MAb data obtained by flow cytometry. The sampling times of the cells during the culture were indicated in Fig. 3A. Like the $q_{M A b}$, intracellular MAb content of entrapped 4A2 hybridoma was not enhanced, and rather slightly decreased when compared with those of the cells in the beginning of the culture (Fig. 4A). When the free- 
suspended cells recovered from the beads were subcultured, intracellular MAb contents of the cells like the $q_{M A b}$ increased to the same level of the cells at the beginning of the culture. Figure 4B shows intracellular MAb data of the free-suspended cells and entrapped cells coexisting in the culture. Because more than two thirds of medium was changed per day, most of freesuspended cells during the entrapped cell culture are thought to be the cells released from the alginate beads. Accordingly, intracellular MAb histograms of the freesuspended cells are those of the cells previously located in the outer layer of alginate beads. The intracellular MAb content of the free-suspended cells was higher than that of the entrapped cells, indicating that the cells in the outer layer of the alginate beads have higher MAb content than the rest of the cells in the beads.

Although the $q_{M A b}$ of entrapped cells was not enhanced, the volumetric MAb productivity, $r_{M A b}$, could be enhanced due to high cell concentration. When the medium was changed twice a day, the average $r_{M A b}$ of the entrapped cells was $121.97 \pm 14.70$ $\mu \mathrm{g} / \mathrm{m} / \mathrm{day}$. This value is approximately 4 times higher than that of free-suspended cells in a control experiment, which was $29.37 \pm 4.11 \mu \mathrm{g} / \mathrm{ml} /$ day.

\section{DB9G8 hybridoma}

\section{Free-suspended (non-entrapped) cell culture}

Like 4A2 hybridoma, a free-suspended cell culture of DB9G8 hybridoma was carried out in a spinner flask as a control experiment. An initial cell concentration was approximately $1.4 \times 10^{5}$ cells $/ \mathrm{ml}$. In order to maintain the cells in exponential growth phase, the cells were diluted 1:4 with fresh medium every other day (Fig. $5 \mathrm{~A})$. Average specific growth rate of the cells was 0.99 $\pm 0.18 /$ day.

The glucose and lactate concentrations during the culture were measured (Fig. 5B). The average $q_{g l u}$ and $q_{g l u}$ were $6.79 \pm 1.07$ and $10.81 \pm 1.71 \mathrm{mmol} / 10^{9}$ cells/day, respectively. The average ratio of lactate produced to glucose consumed, $Y_{l a c / g l u}$, was 1.60 $\pm 0.14 \mathrm{mmol} / \mathrm{mmol}$.

MAb concentrations and $q_{M A b}$ are shown in Fig. 5C. Unlike 4A2 hybridoma, the $q_{M A b}$ of DB9G8 hybridoma was almost constant during the culture. Inoculum used in this study (DB9G8 hybridoma) was also prepared by subculturing six times after thawing. Thus, the early loss of $q_{M A b}$ of the cells after the recent thawing from liquid nitrogen appears to be cell line- specific. The average $q_{M A b}$ of DB9G8 hybridoma was $23.49 \pm 5.46 \mu \mathrm{g} / 10^{6}$ cells/day.

\section{Entrapped cell culture}

Three different sets of entrapped cell cultures were carried out in spinner flasks.

First, the cells entrapped in 0.9-mm-diameter alginate beads were cultivated to determine whether entrapment of DB9G8 hybridoma into calcium alginate beads significantly enhances the $q_{M A b}$. Figure $6 \mathrm{~A}$ shows the growth characteristics of the entrapped cells. An initial viable cell concentration and cell viability were $1.0 \times 10^{6}$ cells $/ \mathrm{ml}$ of medium and $79 \%$, respectively. Like $4 \mathrm{~A} 2$ hybridoma, the viable cell concentration significantly dropped for the first 5 days of cultivation. The viable cell concentration increased from $0.3 \times 10^{6}$ cells $/ \mathrm{ml}$ to $1.9 \times 10^{6} \mathrm{cells} / \mathrm{ml}$ for the next 3 days of cultivation. The cell viability also improved from $21 \%$ to $43 \%$ during this period. Like 4A2 hybridoma, subsequent cell growth produced big clusters of the cells throughout the alginate beads, and not linear spindle-shaped clusters of the cells. The maximum viable cell concentration of $2.9 \times 10^{6}$ cells $/ \mathrm{ml}$ was achieved on day 10 , and thereafter, the viable cell concentration gradually decreased to $2.3 \times 10^{6}$ cells $/ \mathrm{ml}$ by the end of entrapped cell culture. After day $10,60-65 \mathrm{ml}$ of spent medium was replaced by fresh medium twice a day. The free-suspended cell concentration in the culture medium during the entrapped cell culture was less than $1.0 \times 10^{5}$ cells $/ \mathrm{ml}$ which was neglected in the estimation of viable cell concentration in the entrapped cell culture. The cell viability of the free-suspended cells recovered from the calcium alginate beads improved by subsequent sub-cultures. After three passages, the cell viability went up to approximately $80 \%$, which is close to the initial cell viability. Figure 6B shows the glucose and lactate concentrations during the culture. Glucose consumption and lactate production showed a similar pattern of changes in viable cell concentrations during the culture. Glucose consumption and lactate production decreased for the first 5 day of cultivation, and gradually increased until the viable cell concentration reached a maximum. The values of $q_{g l u}$ and $q_{l a c}$ were significantly varied during the first 9 days of cultivation, probably because of dramatic changes in viable cell concentration during this period. The $q_{g l u}$ and $q_{l a c}$ of entrapped cells during the stationary phase of growth were stabilized at $4.55 \pm 0.62$ and $7.41 \pm 1.24 \mathrm{mmol} / 10^{9}$ cells/day, respectively. These values were lower than the val- 


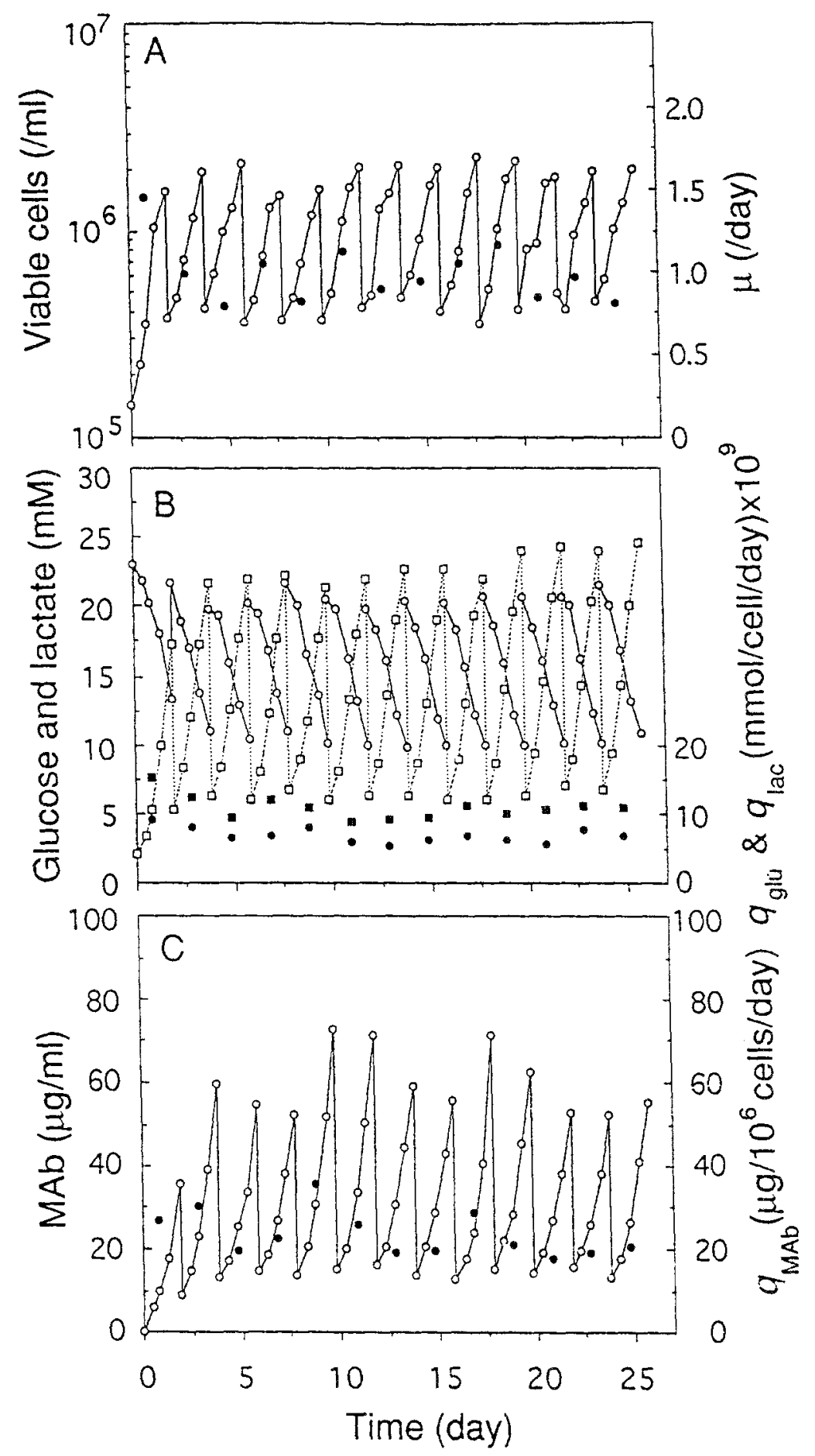

Fig. 5. Free-suspended DB9G8 hybridoma culture. (A) viable cell concentration (o) and specific growth rate, $\mu,(\bullet)$. (B) Glucose concentration

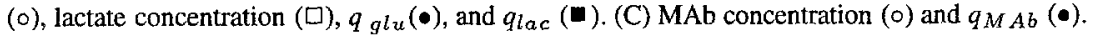




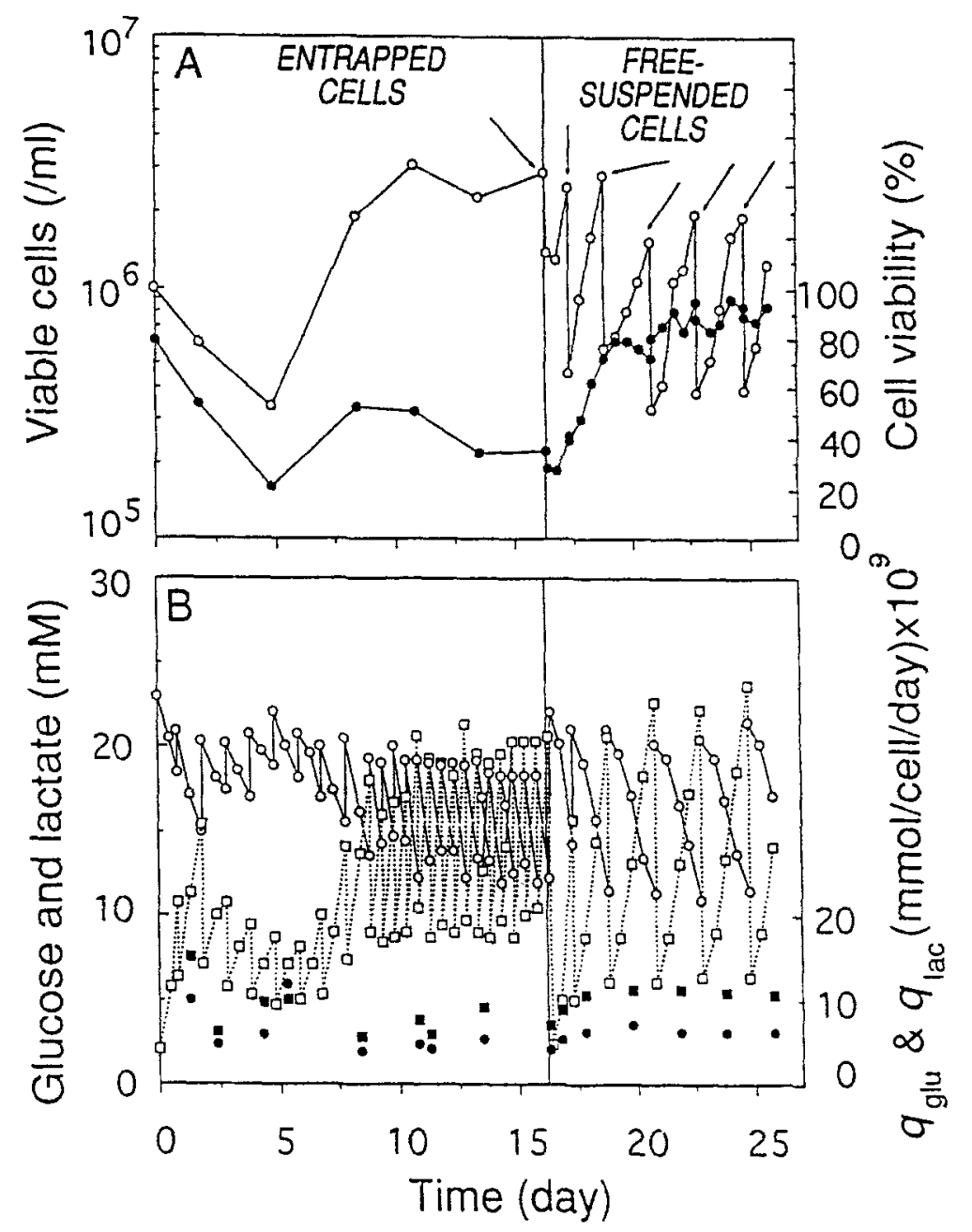

Fig. $6 a-b$.

ues obtained in the free-suspended cell culture. When the free-suspended cells recovered from the beads were subcultured, the $q_{g l u}$ and $q_{l a c}$ of the cells rapidly increased to the same level of the free-suspended cells in a control experiment. Like 4A2 hybridoma, when DB9G8 hybridoma resumed to grow after experiencing a notable loss of viability, the $Y_{l a c / g l u}$ of entrapped cells was significantly lower than the rest of values obtained during the culture. The $Y_{\text {lac } / g l u}$ of entrapped cells on day 5 was $0.83 \mathrm{mmol} / \mathrm{mmol}$, while the average of entrapped cells during the rest of culture was $1.56 \pm 0.13 \mathrm{mmol} / \mathrm{mmol}$. Thus, the low value of $Y_{l a c / g l u}$ of entrapped cells may become an indicator of revival of the cells. Figure $6 \mathrm{C}$ shows the MAb concentrations and $q_{M A b}$ during the culture. Like 4A2 hybridoma, the enhanced $q_{M A b}$ of the entrapped DB9G8 hybridoma was observed only during the ear- ly stage of culture when the cells were dying. Average $q_{M A b}$ of the entrapped cells for the first 5 days of cultivation was $51.64 \pm 8.54 \mu \mathrm{g} / 10^{6}$ cells/day. This enhanced $q_{M A b}$ disappeared as the cells resumed to grow. When the medium was replaced twice a day, the average $q_{M A b}$ of the entrapped 4A2 hybridoma was $25.44 \pm 4.44 \mu \mathrm{g} / 10^{6}$ cells/day, which is close to the

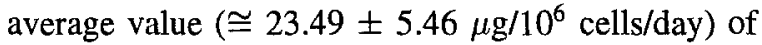
free-suspended cells in a control experiment. When the free-suspended cells recovered from the alginate beads were subcultured, no significant change in $q_{M A b}$ was observed. Although the $q_{M A b}$ of entrapped cells was not enhanced, the volumetric MAb productivity, $r_{M A b}$, could be enhanced due to high cell concentration. When the medium was changed twice a day, the average $r_{M A b}$ of the entrapped cells was $68.43 \pm$ $13.81 \mu \mathrm{g} / \mathrm{ml} /$ day. This value is approximately 3 times 

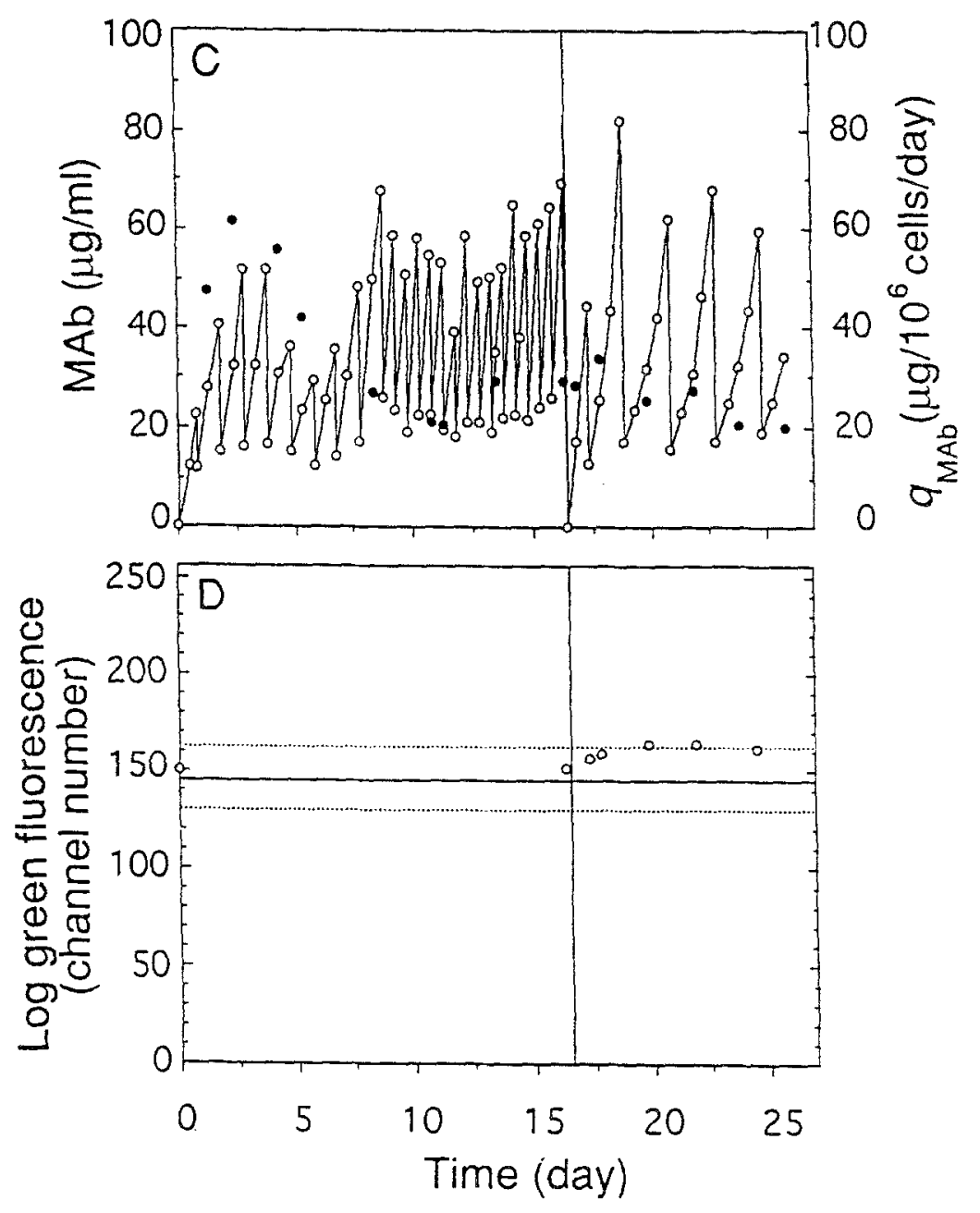

Fig. $6 c-d$.

Figs. 6(a)-(d). Entrapped DB9G8 hybridoma culture followed by free-suspended DB9G8 hybridoma culture. (A) viable cell concentration ( 0 )

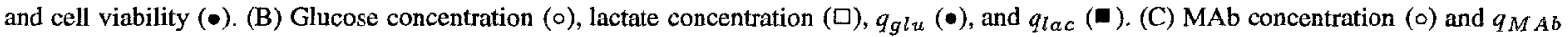
$(\bullet)$. (D) Intracellular MAb content (O). The solid line represents an average value of intracellular MAb contents of free-suspended cells in a control experiment (Fig. 5). The dotted line represents $\pm 2 \mathrm{SD}$.

higher than that of free-suspended cells in a control experiment, which was $22.80 \pm 4.08 \mu \mathrm{g} / \mathrm{ml} /$ day. Fig. ure $6 \mathrm{D}$ shows the intracellular MAb data obtained by flow cytometry. The sampling times of the cells during the culture were indicated in Fig. 6A. Like the $q_{M A b}$, intracellular MAb content of entrapped hybridoma at the end of the entrapped cell culture was not enhanced when compared with those of the cells in the beginning of the culture. Since the intracellular MAb contents of entrapped cells which had the enhanced $q_{M A B}$ were not measured, it is unknown that the intracel- lular MAb contents of entrapped cells were constant throughout the entrapped cell culture. When the freesuspended cells recovered from the beads were subcultured, the intracellular MAb contents were slightly elevated when compared with those of the cells at the end of the entrapped cell culture.

Second, the cell entrapped in 1.2-mm-diameter alginate beads were cultivated to determine whether the size of alginate beads significantly influences the $q_{M A b}$. For comparison, the data obtained from an experiment with 0.9 -mm-diameter-alginate beads 


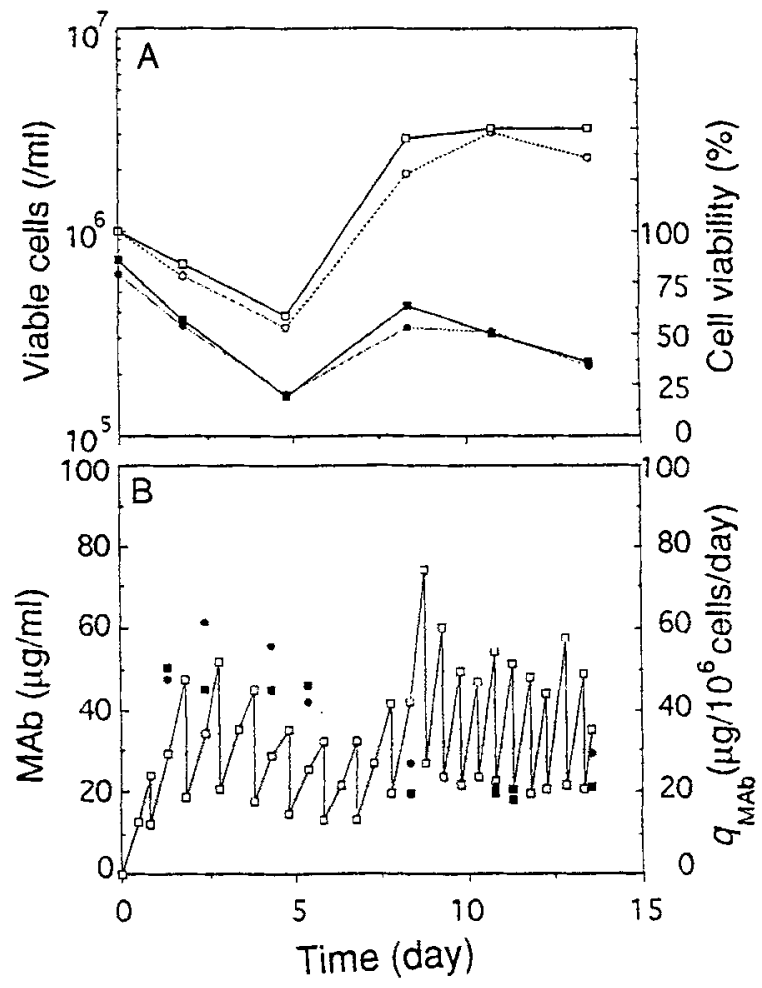

Fig. 7. Entrapped DB9G8 hybridoma culture: effect of bead size. (A) 0.9-mm-diameter bead, viable cell concentration $(0)$ and cell viability $(\bullet) ; 1.2-\mathrm{mm}$-diameter bead; viable cell concentration (ㅁ) and cell viability ( $\bullet$ ). (B) 0.9-mm-diameter bead, $q_{M A b}(\bullet)$; 1.2-mm-diameter bead; MAb concentration ( $\square$ ) and $q_{M A b}(\square)$.

(refer to Fig. 6) were plotted together with those obtained from an experiment with 1.2-mm-diameteralginate beads in Fig. 7. Both experiments were carried out at the same time with the same inoculum. Figure 7A shows the growth characteristics of the entrapped cells in 1.2-mm-diameter alginate beads. An initial viable cell concentration was $1.0 \times 10^{6}$ cells $/ \mathrm{ml}$ of medium. Although the viable cell concentration in $1.2-\mathrm{mm}$ diameter alginate beads was slightly higher than that in $0.9-\mathrm{mm}$-alginate beads, the growth characteristics of the entrapped cells in 1.2-mm-diameter alginate beads were very similar to those in $0.9-\mathrm{mm}$-alginate beads. Figure $7 \mathrm{~B}$ shows the MAb concentration and $q_{M A b}$ of the cells entrapped in 1.2-mm-diameter alginate beads. Like the growth characteristics, MAb production characteristics of the entrapped cells in 1.2-mm-diameter alginate beads were very similar to those in $0.9-\mathrm{mm}$ diameter alginate beads. The entrapped cells in 1.2$\mathrm{mm}$-diameter alginate beads also showed the enhanced $q_{M A b}$ in the beginning of the culture when the cells

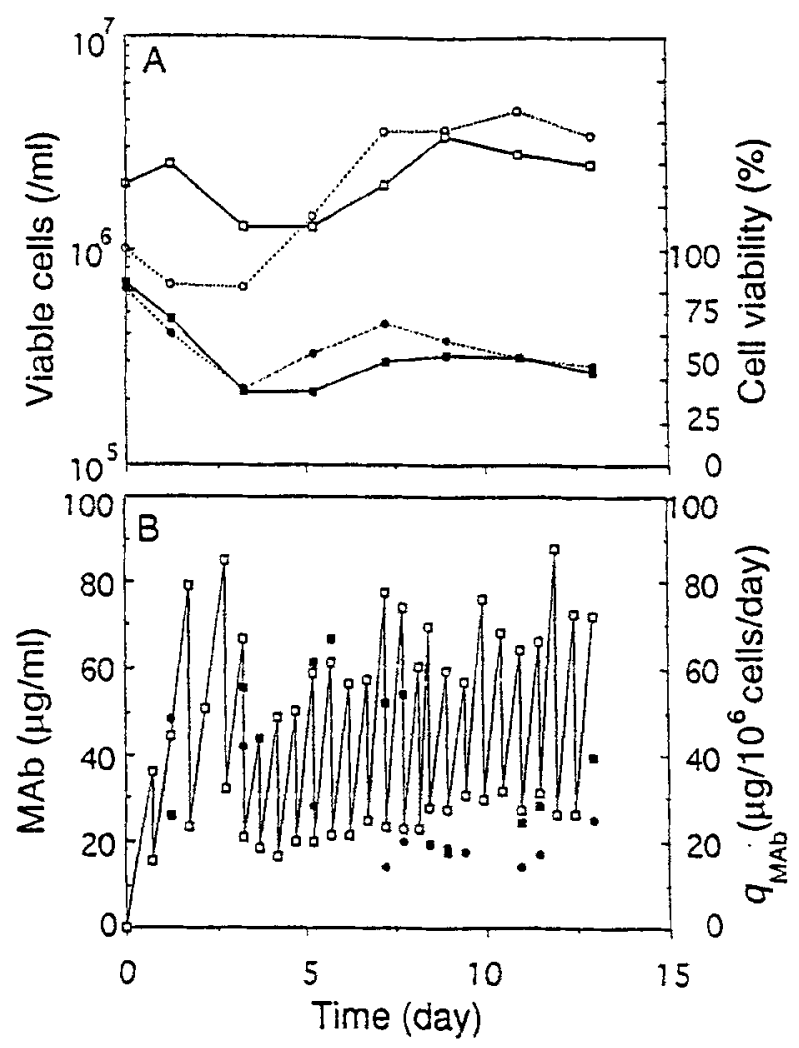

Fig. 8. Entrapped DB9G8 hybridoma culture: effect of initial cell concentration. (A) initial cell concentration of $1 \times 10^{6}$ cells $/ \mathrm{ml}$, viable cell concentration $(0)$ and cell viability $(\bullet)$; initial cell concentration of $2 \times 10^{6}$ cells $/ \mathrm{ml}$; viable cell concentration ( $\square$ ) and cell viability ( $)$. (B) initial cell concentration of $1 \times 10^{6} \mathrm{cells} / \mathrm{ml}$, $q_{M A B}(\bullet)$; initial cell concentration of $2 \times 10^{6} \mathrm{cells} / \mathrm{ml}$, MAb concentration (ㅁ) and $q_{M A b}(\mathbf{E})$.

were dying. Thus, it appears that the bead size tested here dose not influence the $q_{M A b}$ of entrapped cells.

Third, the cells entrapped in 0.9-mm-diameter alginate beads with two different initial cell concentrations were cultivated to determine whether the initial cell concentration in alginate beads can influence the $q_{M A b}$ of the entrapped cells. In addition, by applying a high initial cell concentration, we may be able to achieve a high cell concentration under the stressful condition where the entrapped cells have the enhanced $q_{M A b}$. Two different initial concentrations used were $1.0 \times$ $10^{6}$ and $2.0 \times 10^{6}$ cells $/ \mathrm{ml}$ of medium, respectively. Both experiments were carried out at the same time with the same inoculum. Figure $8 \mathrm{~A}$ shows the growth characteristics of the entrapped cells with different initial cell concentrations. An attempt to maintain a high viable cell concentration from the beginning of the culture by applying a high initial cell concentration 
showed a limited success. Although a viable cell concentration during the lag phase was higher with an initial cell concentration of $2.0 \times 10^{6}$ cells $/ \mathrm{ml}$ than with an initial cell concentration of $1.0 \times 10^{6} \mathrm{cells} / \mathrm{ml}$, the viable cell concentration decreased in the beginning of the culture regardless of initial cell concentrations used. When the initial cell concentration was $2.0 \times$ $10^{6} \mathrm{cells} / \mathrm{ml}$, the viable cell concentration decreased to $1.2 \times 10^{6} \mathrm{cells} / \mathrm{ml}$ for the first 5 days of cultivation, and thereafter, resumed to grow. The entrapped cells with an initial cell concentration of $2.0 \times 10^{6}$ cells $/ \mathrm{ml}$ had approximately 8 days of lag phase which is longer than that of the entrapped cells with an initial cell concentration of $1.0 \times 10^{6}$ cells $/ \mathrm{ml}$. Figure $8 \mathrm{~B}$ shows the MAb concentrations and $q_{M A b}$ of the entrapped cells with different initial cell concentrations. To avoid the complexity of a figure, we plotted only $q_{M A b}$ for the entrapped cells with an initial cell concentration of 1.0 $\times 10^{6}$ cells $/ \mathrm{ml}$. With an initial cell concentration of 2.0 $\times 10^{6}$ cells $/ \mathrm{ml}$, the changes in $q_{M A b}$ during the culture showed the similar trends to those with an initial cell concentration of $1.0 \times 10^{6} \mathrm{cells} / \mathrm{ml}$. At an initial cell concentration of $2.0 \times 10^{6} \mathrm{cells} / \mathrm{ml}$, the entrapped cells showed the enhanced $q_{M A b}$ only during the lag phase. Due to the extended lag phase, the enhanced $q_{M A b}$ was observed for the first 8 days of cultivation and thereafter, disappeared. The data obtained on day 5 clearly shows that the enhanced $q_{M A b}$ of entrapped cells was not due to the low cell concentration when the cells were dying. On day 5 , the viable cell concentrations in the experiments with different initial cell concentrations were similar. However, the entrapped cells with an initial cell concentration of $1.0 \times 10^{6}$ cells $/ \mathrm{ml}$ were actively growing while the entrapped cells with an initial cell concentration of $2.0 \times 10^{6}$ cells $/ \mathrm{ml}$ were still in the lag phase. The $q_{M A b}$ of entrapped cells with an initial cell concentration of $1.0 \times 10^{6}$ cells $/ \mathrm{ml}$ was 28.29 $\mu \mathrm{g} / 10^{6}$ cells/day while the $q_{M A b}$ of entrapped cells with an initial cell concentration of $2.0 \times 10^{6} \mathrm{cells} / \mathrm{ml}$ was $64.24 \mu \mathrm{g} / 10^{6}$ cells/day. Thus, the enhanced $q_{M A b}$ of entrapped cells in the beginning of the culture was not just due to the low cell concentration.

\section{Discussion and conclusions}

As outlined in the Introduction, one of the unresolved issues surrounding $q_{M A b}$ enhancement in calcium alginate-entrapped cells is to determine whether the enhanced $q_{M A b}$ is cell-line specific. Thus, we cultivated calcium alginate-entrapped murine hybridomas under the same condition where we observed the significantly enhanced $q_{M A b}$ of calcium alginate-entrapped S3H5/ $\gamma 2$ bA2 hybridoma (Lee et al., 1991a, 1993).

Two murine hybridomas used in this study were 4A2 and DB9G8 hybridomas. Both hybridomas have been extensively studied in the literature (Heath, 1988; Hiller et al., 1991, 1993; Lee and Palsson, 1993a; Mancuso et al., 1990; McKinney et al, 1991). Since physiological properties of hybridomas can change during the passages, there might be some difficulties in directly comparing the results obtained here with those in the literature. Some of the features of hybridomas used here are as follows. The $q_{M A b}$ of a slow-growing, high concentration culture of $4 \mathrm{~A} 2$ hybridoma in a hollow fiber reactor with high porosity and large pore size, was almost identical to that of free-suspended cells in continuous suspension culture at low dilution rate (Mancuso et al., 1990). Accordingly, we may be able to compare the $q_{M A b}$ of calcium alginate-entrapped cells indirectly with that of the cells in the hollow fiber reactor. It has been suggested that DB9G8 hybridoma has an upper limit for MAb concentration in the culture medium as the $q_{M A b}$ dropped to zero around $27-36 \mu \mathrm{g} / \mathrm{ml}$ antibody (McKinney et al., 1991). It may thus be informative to monitor the changes in $q_{M A b}$ of the calcium alginate-entrapped DB9G8 hybridoma during the culture.

Calcium alginate-entrapped 4A2 and DB9G8 hybridomas showed the very similar changes in $q_{M A b}$ during culture. For calcium alginate-entrapped $\mathrm{S} 3 \mathrm{H} 5 / \gamma 2 \mathrm{bA} 2$ hybridoma, the $q_{M A b}$ as well as the intracellular MAb content was significantly enhanced since the maximum cell concentration was achieved. Unlike $\mathrm{S} 3 \mathrm{H} 5 / \gamma 2 \mathrm{bA} 2$ hybridoma, neither $4 \mathrm{~A} 2$ nor DB9G8 hybridomas showed the persistently enhanced $q_{M A b}$ when they were entrapped in calcium alginate beads. A similar observation has been reported for the 63D3 hybridoma (Wohlpart et al., 1991). Thus, the enhanced $q_{M A b}$ of calcium alginateentrapped hybridomas appears to be cell-line specific. The enhanced $q_{M A b}$ of entrapped $4 \mathrm{~A} 2$ and DB9G8 hybridomas, which was 2-3 times higher than the $q_{M A b}$ of free-suspended cells in a control experiment, was observed only during the early stage of the culture. As the cells resumed to grow, this enhanced $q_{M A b}$ decreased to the similar level of $q_{M A b}$ of freesuspended cells in a control experiment. The intracellular MAb content of entrapped cells at the end of entrapped cells was also comparable to that of freesuspended cells in a control experiment. During the early stage of the culture, a viable cell concentration 
was decreasing probably due to cell damage during the entrapment process. However, the enhanced $q_{M A b}$ of entrapped cells during the early stage of the culture was not just due to a low cell concentration, as indicated by the results from experiments with varying initial cell concentrations (refer to Fig. 8). Further, released antibody from dead cells did not account for the enhanced $q_{M A b}$ because the antibody contained in viable and dead cells together accounted for less than $10 \%$ of the total extracellular antibody (Meilhoc et al., 1989; Passini and Goochee, 1989; Reddy et al., 1992). Accordingly, the enhanced $q_{M A b}$ of entrapped cells was likely to be due to the stressful culture condition induced by entrapment. After the cells adapted to a new microenvironment in the beads, the entrapment might not provide the stressful culture condition to the cells any longer. Thus, when the cells resumed to grow, the enhanced $q_{M A B}$ of entrapped cells might disappear.

In our previous report, we suggested three possible reasons for the enhanced $q_{M A b}$ of entrapped $\mathrm{S} 3 \mathrm{H} 5 / \gamma 2 \mathrm{bA} 2$ hybridoma: slowed growth rate, stressful conditions, and presence of autocrine growth factors (Lee et al., 1991a). Stressful culture conditions would also result in slowed cell growth rate. The $q_{M A b}$ of $\mathrm{S} 3 \mathrm{H} 5 / \gamma 2 \mathrm{bA} 2$ hybridoma was elevated at slowed growth rates in free-suspended cell cultures (Lee et al., 1989). However, when the entrapped $\mathrm{S} 3 \mathrm{H} 5 / \gamma 2 \mathrm{bA} 2$ hybridoma had slowed growth rate and was under stressful conditions, the $q_{M A b}$ was not always enhanced (Lee et al., 1993). Cultivation methods determined the extent of enhancement of $q_{M A b}$ of entrapped $\mathrm{S} 3 \mathrm{H} 5 / \gamma 2 \mathrm{bA} 2$ hybridoma. Thus, slowed growth rate and stressful conditions of the entrapped cells do not directly account for the enhanced $q_{M A b}$ of entrapped $\mathrm{S} 3 \mathrm{H} 5 / \gamma 2 \mathrm{bA} 2$ hybridoma. This study also shows that slowed growth rate itself does not always enhance the $q_{M A b}$. In addition, the $q_{M A B}$ of $4 A 2$ hybridoma was reported to be non-growth associated (Hiller et al., 1991). As discussed earlier, the transiently enhanced $q_{M A b}$ of $4 \mathrm{~A} 2$ and DB9G8 hybridomas is likely due to stressful conditions. Thus, even when the $q_{M A b}$ is enhanced by entrapment, the reason for the enhanced $q_{M A b}$ of entrapped cells appears to be different among cell lines. Different responses of the cells to entrapment are probably because of the nature of hybridoma cells. Since hybridomas are the randomly fused cells between immortalized myeloma and antibody-producing lymphocytes, their properties are expected to be very different. For example, 4A2 and DB9G8 hybridomas showed similar responses to entrapment with regard to their MAb production. How- ever, they showed different response to stress induced by freezing and thawing with regard to their MAb production. Further, the production of autocrine growth factors and inhibitory factors was also found to be cell-line dependent (Kidwell, 1989). Accordingly, as shown in this study, it is unlikely for all the hybridomas to show similar response to cell entrapment with regard to their MAb production.

The results reported here may be compared with those in the literature (Mancuso et al., 1990; McKinney et al., 1991). For 4A2 hybridoma, like the $q_{M A b}$ of a slow-growing, high concentration culture of $4 \mathrm{~A} 2$ hybridoma cells in a hollow fiber reactor with high porosity and large pore size, the $q_{M A b}$ of calcium alginate-entrapped cells was similar to that of freesuspended cells in a control experiment. Thus, calcium alginate bead does not provide $4 \mathrm{~A} 2$ hybridoma with a unique environment to improve the $q_{M A b}$. For DB9G8 hybridoma, we did not find any MAb feedback inhibition. However, as we mentioned earlier, direct comparison may be difficult because culture history was different. In addition, different medium was used here.

In conclusion, unlike $\mathrm{S} 3 \mathrm{H} 5 / \gamma 2 \mathrm{bA} 2$ hybridoma, both 4A2 and DB9G8 hybridomas did not show the persistently enhanced $q_{M A b}$ when they were entrapped in calcium alginate beads. Thus, the enhanced $q_{M A b}$ of calcium alginate-entrapped hybridomas appears to be cell-line specific. Although calcium alginate entrapment did not enhance the $q_{M A b}$ of $4 \mathrm{~A} 2$ and DB9G8 hybridomas, it did enhance the volumetric MAb productivity because of high cell concentration. For both cell lines, the volumetric MAb productivity in entrapped cell culture was approximately 3-4 times higher than that in free-suspended cell culture. As long as entrapment does not deteriorate the $q_{M A b}, \mathrm{MAb}$ production using entrapped cells may be feasible.

\section{Acknowledgements}

The Xoma's hybridoma cell line 4A2 and antibody standards were generously provided by the Xoma Corporation. Alginate was generously provided by the Kelco company. This work was supported by the National Science Foundation (BSC-9009389) and the Korea Science and Engineering Foundation (KOSEF). We would like to thank Dr. Frank Castillo for many valuable discussions regarding the Xoma's hybridoma cell line 4A2. We also thank Mehran Shahabi for his help in flow cytometry. 


\section{References}

De la Broise D, Noiseux M, Massie B and Lemieux R (1992) Hybridoma perfusion systems: A comparison study. Biotechnol. Bioeng. 40: 25-32.

Heath C (1988) Engineering aspects of improved antibody production by hybridomas. Ph.D. thesis. Rensselaer Polytechnic Institute, Troy, NY, USA.

Hiller GW, Aeschlimann AD, Clark DS and Blanch HW (1991) A kinetic analysis of hybridoma growth and metabolism in continuous suspension culture on serum-free medium. Biotech. Bioeng. 38: 733-741.

Hiller GW, Clark DS and Blanch HW (1993) Cell retentionchemostat studies of hybridoma cells-analysis of hybridoma growth and metabolism in continuous suspension culture on serum-free medium. Biotech. Bioeng. 42: 185-195.

Kidwell W (1989) Filtering out inhibition. Bio/Technol. 7: 462-463.

Lee GM, Huard TK and Palsson BO (1989) Effect of serum concentration on hybridoma cell growth and monoclonal antibody production at various initial cell densities. Hybridoma 8: 369375.

Lee GM and Palsson BO (1990) Immobilization can improve the stability of hybridoma antibody productivity in serum-free media. Biotechnol. Bioeng. 36: 1049-1055.

Lee GM, Varma A and Palsson BO (1991a) Production of monoclonal antibody using free-suspended and immobilized hybridoma cells: Effect of serum. Biotechnol. Bioeng. 38: 821-830.

Lee GM, Gray JJ and Palsson BO (1991b) Effect of trisodium citrate treatment on hybridoma cell viability. Biotechnol. Technique 5: 295-298.

Lee GM, Han BK, Kim JH and Palsson BO (1992) Effect of calcium chloride treatment on hybridoma cell viability and growth. Biotechnol. Lett. 14: 891-896.

Lee GM, Chuck AS and Palsson BO (1993) Cell culture conditions determine the enhancement of specific monoclonal antibody productivity of calcium alginate-entrapped $\mathrm{S} 3 \mathrm{H} 5 / \gamma 2 \mathrm{bA} 2$ hybridoma cells. Biotechnol. Bioeng. 41: 330-340.

Lee GM and Palsson BO (1993a) Stability of antibody productivity is improved when hybridoma cells are entrapped in calcium alginate beads. Biotechnol. Bioeng. 42:1131-1135.

Lim F (1984) Microencapsulation of living cells and tissues. In: Lim F (ed.) Biomedical Application of Microencapsulation. (pp.137154) CRC Press, Boca Raton, FL, USA.

Lim F (1988) Microencapsulation of living mammalian cells. In: Mizrahi A (ed.) Upstream Processes: Equipment and Techniques. (pp.185-197) Alan R. Liss, New York.
Mancuso A, Femandez EJ, Blanch HW and Clark DS (1990) A nuclear magnetic resonance technique for determining hybridoma cell concentration in hollow fiber bioreactors. Bio/Technol. 8: 1282-1285.

McKinney KL, Dilwith R and Belfort G (1991) Manipulation of heterogeneous hybridoma cultures for overproduction of monoclonal antibodies. Biotechnol. Prog. 7: 445-454.

Meilhoc E, Wittrup KD and Bailey JE (1989) Application of flow cytometric measurement of surface IgG in kinetic analysis of monoclonal antibody synthesis and secretion by murine hybridoma cells. J. Immunol Methods 121: 167-174.

Miller WM (1987) A kinetic analysis of hybridoma growth and metabolism. Ph.D. thesis, University California, Berkeley, CA, USA.

Passini CA and Goochee CF (1989) Response of a mouse hybridoma cell line to heat shock, agitation, and sparging. Biotechnol. Prog. 5: $175-188$.

Ray NG, Vournakis JN, Runstadler PW, Tung AS and Venkatasubramanian K (1990) Physiology of hybridoma and recombinant Chinese Hamster Ovary cells immobilized in collagen matrix, In: de Bont JAM, Visser J, Mattiasson B and Tramper J (eds.), Physiology of Immobilized Cells. (pp. 699-711) Elsevier, Amsterdam.

Reddy S, Bauer KD and Miller WM (1992) Determination of antibody content in live versus dead hybridoma cells: analysis of antibody production in osmotically stressed cultures. Biotechnol. Bioeng. 40: 947-964.

Schroer, JA, Bender T, Feldmann RJ and Kim KJ (1983) Mapping epitopes on the insulin molecule using monoclonal antibodies. Eur. J. Immunol. 13: 693-700.

Shen BQ, Reid G and Greenfield PF (1992) Continuous monoclonal antibody production by a composite gel perfusion reactor in a protein-free medium, In: Murakami H, Shirahata S and Tachibana $\mathrm{H}$ (eds.), Animal Cell Technology: Basic and Applied Aspects. (pp.173-178) Kluwer Academic Publishers, Dordecht.

Shirai Y, Hashimoto K, Yamaji H and Tokashiki M (1987) Continuous production of monoclonal antibody with immobilized hybridoma cells in an expanded bed fermentor. Appl. Microbiol. Biotechnol. 26:495-499.

Sinacore MS, Creswick BC and Buehler R (1989) Entrapment and growth of murine hybridoma cells in calcium alginate gel microbeads. Bio/Technol. 7: 1275-1279.

Wohlpart D, Gainer J and Kirwan D (1991) Oxygen uptake by entrapped hybridoma cells. Biotechnol. Bioeng. 37: 1050-1053. 